UDK 632.935:632.954:633.34

Naučni rad - Scientific paper

\title{
Effects of timing of weed removal and application of pre-emergence herbicides on growth of soybeans
}

\author{
Pavle Pavlović1 ${ }^{1}$ Adewale Osipitan ${ }^{2}$, Stevan Z. Knežević ${ }^{2}$ \\ 1University of Belgrade, Faculty of Agriculture, Nemanjina 6, Belgrade-Zemun 11080, Serbia \\ ${ }^{2}$ Northeast Research and Extension Center, Department of Agronomy and Horticulture, \\ University of Nebraska, Concord, NE 68728, USA \\ e-mail: pavlepavlov93@gmail.com
}

\section{SUMMARY}

Field studies were conducted in 2017 at Concord in northeast Nebraska to evaluate how timing of weed removal and application of pre-emergence (PRE) herbicides influences the growth of soybean. The studies were laid out in a split-plot arrangement of 14 treatments ( 2 herbicide regimes and 7 weed removal timings) with four replicates. The 2 herbicide regimes were: No PRE and PRE application of a premix of sulfentrazone plus imazethapyr (140 plus $28 \mathrm{~g}$ ai ha- ${ }^{-1}$. The 7 weed removal timings were: V1, V3, V6, R2 and R5 soybean growth stages, as well as weed free and weedy season long. Soybean growth parameters (leaf area and dry matter) were collected at R6 growth stage. Delayed timing of weed removal significantly influenced the soybean growth by reducing leaf area and dry matter. Without the application of PRE herbicides, a 5\% reduction in soybean leaf area and dry matter occurred when weed removal was delayed until 100 growing degree days after emergence (GDD; equivalent to V1 soybean stage or 10 days after emergence [DAE]). Meanwhile, the use of PRE herbicide prevented the same level of reduction until 382 GDD (V5 soybean stage; $34 \mathrm{DAE}$ ). The practical implication is that the use of PRE herbicides protected soybean growth and delayed the need for post-emergence application of herbicides by three weeks after soybean emergence.

Keywords: weed interference, soybean, pre-emergence herbicides, crop growth and development.

\section{INTRODUCTION}

In modern agriculture, the practice that is most often employed against weeds involves herbicide application. The repeated use of a single mode of herbicide action has resulted 
in increasing cases of herbicide resistant (HR) weeds. Globally there are over $400 \mathrm{HR}$ weed biotypes among $210 \mathrm{HR}$ weed species (Heap and Duke, 2018). How costly the control of HR weed species can be, is well demonstrated in western Canada where wild oat (Avena fatua L.) is the most dominant HR weed (Beckie et al., 2013). Over \$500 million annually is spent on wild oat control alone, more than any other weed species (Leeson et al., 2006).

With the commercialization and adoption of glyphosate-tolerant (GT) crops (including soybean), the use of glyphosate for weed control has increased drastically over the last 20 years (Heap and Duke, 2018). This is true for all states in the Midwestern United States, where GT crops are widely grown. The repeated use of glyphosate has resulted in the development of six glyphosate-resistant weed populations in Nebraska alone (Knezevic, 2007). Others have also reported that there was a shift in weed species from those species easily controlled by glyphosate to those more tolerant to glyphosate (Knezevic and Klein, 2005; Wilson et al., 2005) and to those weed species with growth types or life cycles which avoided the treatment with glyphosate, such as winter annuals (Knezevic, 2006). Diversifying weed control in GT soybeans with the use of PRE herbicides with alternative modes of action will minimize the excessive use of glyphosate and help in managing HR weeds. Thus, there is a need to diversify weed control tactics, in particular through the development of integrated weed management.

Integrated Weed Management (IWM) approach uses weed management tools other than just herbicides. Adopting diversified IWM practices has the potential to slow the evolution of weed resistance to herbicides (Harker, 2013). Timing of weed removal is one of the key components of IWM. Having that information is vital to the grower, since it can provide a guideline for PRE or POST herbicide application. Proper timing of herbicide application can also minimize weed-crop competition (Molugeta and Boerboom, 2000), which can be achieved through the use of the concept of Critical Period for Weed Control (CPWC). The CPWC is a period in the crop growth cycle during which weeds must be controlled to prevent unacceptable yield losses. In essence, the CPWC represents the time interval between two separately measured crop-weed competition components: The Critical Timing of Weed Removal (CTWR) and The Critical Weed-Free Period (CWFP). Knowing the CPWC is useful in making decisions on the need for and timing of weed control and in achieving efficient herbicide use from both biological and economic perspectives (Knezevic et al., 2002).

CTWR is the maximum amount of time early-season weed competition can be tolerated by the crop before the crop suffers irreversible yield reduction. In reality, the CTWR is the beginning stage of the CPWC (Knezevic et al., 2002). CTWR can vary depending on several factors including crop and weed characteristics, environmental variables, cropping practices such as crop planting density and row spacing (Teasdale, 1995; Adigun et al., 2014; Osipitan et al., 2016), soil nutrient (Knezevic et al., 2002) and pre-emergence weed control. Determining the effects of PRE herbicides on the CTWR will aid in optimizing weed control strategies, as well as allow for the development of better resistance management strategies. The objective of this study was to determine how different timings of weed removal, as well as application of PRE herbicides would influence the growth and development of soybeans. 


\section{MATERIALS AND METHODS}

Study and experimental set up. Field study was conducted in 2017 at Haskell Agricultural Laboratory (HAL) Research and Extension Center of University of Nebraska-Lincoln, Concord $\left(42.37^{\circ} \mathrm{N}, 96.68^{\circ} \mathrm{W}\right)$, northeast Nebraska, USA. The soil type was a silty clay loam with $16 \%$ sand, $52 \%$ silt, $32 \%$ clay, $4.7 \%$ organic matter with $\mathrm{pH} 6.1$ and cation exchange capacity (CEC) of 30.8 milliequivalents per $100 \mathrm{~g}$. The soybean was planted on May 15, at 76-cm row spacing with the seeding rate of 370000 seeds ha $^{-1}$ in $8 \mathrm{~m}$ by $3 \mathrm{~m}$ plots. Soybean cultivar (NK SJ-27 GT) was planted with John Deere ${ }^{\circledR}$ Finger Pickup Planter (1819 Chiefs Way, Wayne, NE 68787, USA). In each of the plots (experimental units) there were four crop rows. Prior to planting, the soil was conventionally tilled and no starter fertilizer was applied. The treatments were arranged in a split-plot design with four replications. The two main plots treatments were: No pre-emergence (PRE) herbicides and PRE application of sulfentrazone plus imazethapyr ( 140 plus $28 \mathrm{~g}$ ai ha $\left.^{-1}\right)$. Sub-plots consisted of seven weed removal timings where weeds were allowed to grow until predetermined growth stages of soybean, including: first trifoliate (V1), third trifoliate (V3), sixth trifoliate (V6), full flowering (R2), early seeding (R5), season-long weed-free and season-long weedy treatments.

The average temperatures and overall rainfall ranged from $7-30^{\circ} \mathrm{C}$ and from $14-246 \mathrm{~mm}$, respectively (Table 1). Weeds were removed at the given soybean stage by application of Roundup PowerMAX ${ }^{\circledast}$ (glyphosate, $2000 \mathrm{~g}$ ai ha $^{-1}$ ), with the exception at R2 and R5 soybean growth stages when weed removal was done by hoeing. After the specified removal times, plots were kept weed-free by hoeing for the rest of the season. The PRE herbicides were applied with a $\mathrm{CO}_{2}$-pressurized backpack sprayer equipped with TeeJet AIXR 11002 flat-fan nozzles (Spraying Systems Co., Wheaton, IL, USA) spaced $56 \mathrm{~cm}$ apart calibrated to deliver $1401 \mathrm{ha}^{-1}$ of aqueous solution at $207 \mathrm{kPa}$. POST herbicide applications were also done with a $\mathrm{CO}_{2}$-pressurized backpack sprayer, which was equipped with TeeJet XRC 8002 flat-fan nozzles (Spraying Systems Co., Wheaton, IL, USA), spaced $56 \mathrm{~cm}$ apart, calibrated to deliver 1401 $\mathrm{ha}^{-1}$ of aqueous solution at $207 \mathrm{kPa}$.

Table 1. Total monthly precipitation and average temperature for the growing season

Tabela 1. Ukupne mesečne padavine i prosečne temperature za vegetacioni period

\begin{tabular}{lccc}
\hline \multirow{2}{*}{$\begin{array}{l}\text { Month } \\
\text { Mesec }\end{array}$} & $\begin{array}{c}\text { Precipitation } \\
\text { Padavine }(\mathbf{m m})\end{array}$ & \multicolumn{2}{c}{$\begin{array}{c}\text { Average monthly temperature }\left({ }^{\circ} \mathbf{C}\right) \\
\text { Prosečne mesečne temperature }\end{array}$} \\
\cline { 3 - 4 } May & 94.2 & Min & Max \\
June & 13.9 & 8.3 & 20.6 \\
July & 38.9 & 15 & 29.4 \\
August & 245.6 & 17.8 & 30.6 \\
September & 49.5 & 13.9 & 25 \\
October & 87.9 & 11.7 & 24.4 \\
\hline
\end{tabular}


Growing degree days (GDD) calculation. Soybean growing degree days (GDD) were used as the explanatory variable and calculated using the method described by Gilmore and Rogers (1958). The days after soybean emergence (DAE) and soybean growth stages (SGS) were used as reference points for the accumulation of GDD. Temperatures were recorded hourly with data loggers throughout the growing season. Temperatures were converted to GDD using the following equation (Gilmore and Rogers, 1958):

$$
G D D=\sum\left[\frac{T_{\max }+T_{\min }}{2}\right]-T_{\text {base }}
$$

where $T_{\max }$ and $T_{\min }$ are daily maximum and minimum air temperature $\left({ }^{\circ} \mathrm{C}\right)$ respectively, and $T_{\text {base }}$ is the base temperature $\left(10^{\circ} \mathrm{C}\right)$ for soybean growth.

Data collection. Species composition and weed density for each weed species were measured in all plots, prior to weed removal. Weed counts were conducted with $0.25 \mathrm{~m}^{2}$ quadrats placed in the middle of each plot. Soybean growth data, leaf area and dry matter, were also collected from 6 soybean plants within $30 \mathrm{~cm}$ length from one of the outer rows in each plot. The leaf area of the sampled plants was measured using the leaf area meter (Model LI-3100C). Samples were then dried at $50^{\circ} \mathrm{C}$ for 15 days and dry matter recorded.

Statistical analysis. Regression analysis between plant dry matter (or leaf area) and GDD was conducted using the four-parameter log-logistic model with the following equation (Hall et al., 1992; Knezevic et al., 2007):

$$
Y=\frac{C+(D-C)}{\{1+\exp [B(\log X-\log E)]\}}
$$

where $\mathrm{Y}$ is the response, $\mathrm{C}$ is the lower limit, $\mathrm{D}$ is the upper limit, $\mathrm{X}$ is the GDD calculated after crop emergence, $\mathrm{E}$ is the GDD giving a $50 \%$ response between the upper and lower limit (also known as the inflection point, $\mathrm{I}_{50}$ or $\mathrm{ED}_{50}$ ) and $\mathrm{B}$ is the slope of the line at the inflection point (also known as a rate of change).

The GDD (and the corresponding DAE and SGS) required for 5\% reduction $\left(\mathrm{ED}_{5}\right)$ in dry matter and leaf area, for both No PRE and PRE herbicides treatments, were calculated from the regression curves. The $\mathrm{ED}_{5}$ value was considered as the CTWR. All statistical analysis and graphs were performed using $R$ program (R Development Core Team, 2017), utilizing the dose-response curves $(d r c)$ statistical package (Knezevic et al., 2007).

\section{RESULTS}

Weed density and species composition. Average weed density was 23 plants $\mathrm{m}^{-2}$. The two predominant weed species were Amaranthus tuberculatus (Moq.) J. D. Sauer and Setaria viridis (L.) P. Beauv., accounting for 48 and $27 \%$ of the overall weed population, respectively. Abutilon theophrasti Medik. and Chenopodium album L. accounted for 13 and 12\% of the 
overall weed population, respectively. Other weed species were Amaranthus retroflexus L., Xanthium strumarium L., Helianthus annuus L. and Solanum rostratum Dunal, which all made $1 \%$ of the total weed population (Table 2 ).

Table 2. Average weed density and species composition

Tabela 2. Sastav korovske flore i prosečna gustina korova

\begin{tabular}{llcc}
\hline $\begin{array}{l}\text { Weed species } \\
\text { Vrste korova }\end{array}$ & $\begin{array}{l}\text { Type } \\
\text { Tip }\end{array}$ & $\begin{array}{c}\text { Average density } \\
\text { Prosečna gustina } \\
\text { (plants } \text { m }^{-2} \text { ) }\end{array}$ & $\begin{array}{c}\text { \% accounting of the } \\
\text { overall population } \\
\text { \% zastupljenosti } \\
\text { populacije }\end{array}$ \\
\hline Amaranthus tuberculatus (Moq.) J. D. Sauer & broadleaf & 54.05 & $48.03 \%$ \\
Setaria viridis (L.) P. Beauv. & grass & 29.90 & $26.57 \%$ \\
Abutilon theophrasti Medik. & broadleaf & 15.15 & $13.47 \%$ \\
Chenopodium album L. & broadleaf & 13.09 & $11.64 \%$ \\
Other & broadleaves & 0.33 & $0.30 \%$ \\
\hline
\end{tabular}

Soybean leaf area. There was a reduction in soybean leaf area with increasing delay in weed removal for both No PRE and PRE treatments (Figure 1). The reduction was generally greater in the plots with No PRE treatment compared to PRE treatment. With No PRE, leaf area was reduced by 7, 9, 53, 59 and $64 \%$ as weed removal was delayed until V1, V3, V6, R2 and R5, respectively. Allowing weed competition throughout the soybean growing season resulted in a $71 \%$ leaf area loss, when No PRE herbicides were used (Figure 1). With PRE herbicides treatment, leaf area was reduced by $3-28 \%$ as weed removal was delayed until V1 to R5.

The impact of season-long weed competition on soybean leaf area was relatively lower (about 38\% leaf area loss) in plots with PRE herbicides, when compared to plots with No PRE treatment (71\% leaf area loss).

Based on a $5 \%$ loss in soybean leaf area, the critical time of weed removal (CTWR) in soybean grown without PRE herbicides occurred at 100 GDD (10 DAE) (Figure 2). The 100 GDD coincided with V1 soybean growth stage (Table 3). With PRE herbicides, the CTWR was delayed until 382 GDD (34 DAE) (Figure 2). The 382 GDD coincided with V5 soybean growth stage (Table 3).

Soybean dry matter. Delay in weed removal significantly reduced the soybean dry matter (Figure 3). Weed interference throughout the soybean growing season resulted in $70 \%$ dry matter loss, due to a lack of No PRE herbicides. The earlier the timing of weed removal, the lower the loss in soybean dry matter. For example, the dry matter loss was 6, 8, 45, 48 and $58 \%$ for weed removal timing at V1, V3, V6, R2 and R5 soybean stages, respectively (Figure 3). With PRE herbicides treatment, the dry matter loss was at 5, 6, 11, 16, 22 and 28\% as weed removal was delayed until V1, V3, V6, R2 and R5, respectively. The influence of season-long weed interference on soybean dry matter was relatively lower (33\% dry matter loss) in plots with PRE herbicides, when compared to plots with No PRE treatment (70\% loss).

Similar to leaf area, a 5\% reduction in soybean dry matter occurred at 100 GDD (10 DAE); corresponding to V1 growth stage (Figure 4, Table 4). With PRE herbicides, the same level of 
reduction in soybean dry matter was delayed until 382 GDD (34 DAE); corresponding with V5 soybean growth stage (Figure 4, Table 4).

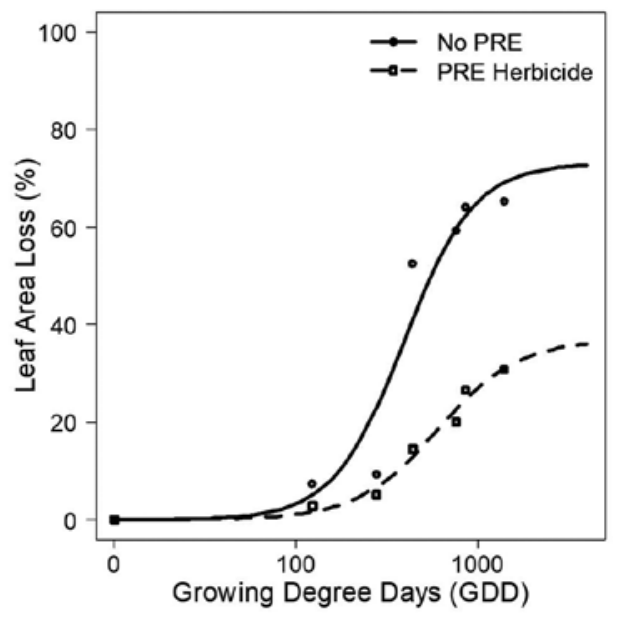

Figure 1. Soybean leaf area loss (\%) as a function of increasing delay of weed removal for No PRE and PRE herbicides applications.

Grafik 1. Gubitak lisne površine (\%) useva soje pri kasnijem uklanjanju korova u varijanti sa i bez PRE-EM primene herbicida.

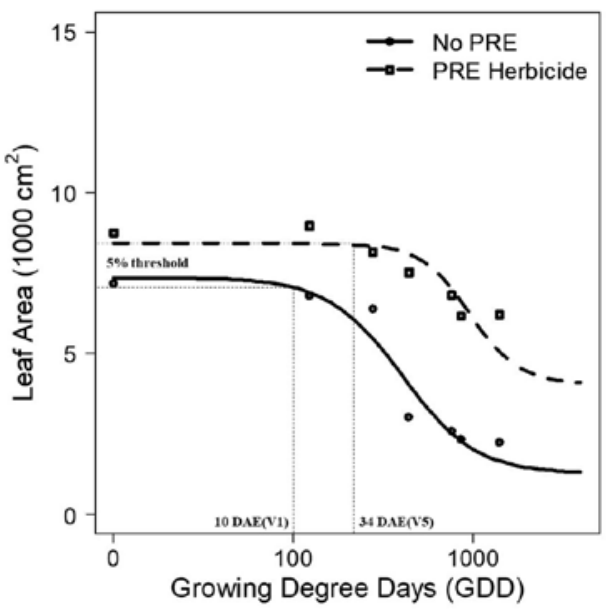

Figure 2. Soybean leaf area $\left(\mathrm{cm}^{2}\right)$ as a function of increasing delay of weed removal for No PRE and PRE herbicides applications. Broken lines predicted with the four-parameter logistic model (Equation 2) used to determine the critical time of weed removal (CTWR) at 5\% reduction. See Table 3 for parameter estimates.

Grafik 2. Uticaj vremena uklanjanja korova na lisnu površinu soje $\left(\mathrm{cm}^{2}\right)$ u varijanti sa i bez zemljišne primene herbicida. Isprekidana linija predstavlja kritični period suzbijanja korova na osnovu redukcije lisne površine od 5\% izračunat na osnovu log-logistic modela nelinearne regresione analize sa četiri parametara (jednačina 2). Vidi tabelu 3 sa procenjenim parametrima. 


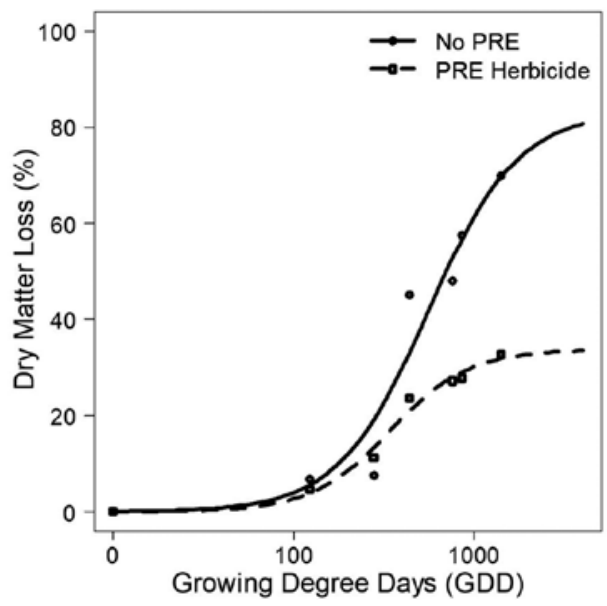

Figure 3. Soybean dry matter loss (\%) as a function of increasing delay of weed removal for No PRE and PRE herbicides applications.

Grafik 3. Gubitak suve mase useva soje (\%) pri kasnijem uklanjanju korova u varijanti sa i bez PRE-EM primene herbicida.

Table 3. Regression parameters estimates showing the slope (B), lower limit (C), upper limit (D), growing degree days $(\mathrm{GDD})$ at $50 \%$ reduction $\left(\mathrm{I}_{50}\right)$ and $\mathrm{GDD}$ at $5 \%$ reduction $\left(\mathrm{ED}_{5}\right)$ for No PRE and PRE herbicides treatments on soybean leaf area. The $\mathrm{ED}_{5}$ value was used to estimate the critical time of weed removal (CTWR).

Tabela 3. Procenjeni parametri regresije pokazuju nagib linije (B), donji limit (C), gornji limit (D), sume efektivnih temperatura $(\mathrm{GDD})$ za redukciju lisne površine soje od $50 \%\left(\mathrm{I}_{50}\right)$ i GDD za redukciju od $5 \%\left(\mathrm{ED}_{5}\right)$ u varijanti sa i bez PRE-EM primene herbicida. Vrednost $\mathrm{ED}_{5}$ je korišćena za procenu kritičnog vremena uklanjanja korova (KVUK).

\begin{tabular}{|c|c|c|c|c|c|c|c|}
\hline \multirow{2}{*}{$\begin{array}{l}\text { Herbicide application } \\
\text { Primena herbicida }\end{array}$} & \multicolumn{4}{|c|}{ Regression parameters / Parametri regresije } & \multirow{2}{*}{ GDD } & \multirow{2}{*}{$\begin{array}{c}\text { ED }_{5} \\
\text { DAE }^{\mathbf{a}}\end{array}$} & \multirow{2}{*}{$\mathbf{S G S}^{\mathrm{b}}$} \\
\hline & B & $\mathrm{C}$ & D & $\mathbf{I}_{50}$ & & & \\
\hline No PRE & $2.11( \pm 0.89)$ & $1.25( \pm 0.32)$ & $7( \pm 0.39)$ & $352( \pm 37)$ & $100( \pm 14)$ & 10 & V1 \\
\hline PRE herbicides & $3.19( \pm 1.97)$ & $4.05( \pm 1.07)$ & $8.86( \pm 0.59)$ & $449( \pm 226)$ & $382( \pm 84)$ & 34 & V5 \\
\hline
\end{tabular}

${ }^{a}$ Days after emergence; ${ }^{b}$ Soybean growth stage

Table 4. Regression parameters estimates showing the slope (B), lower limit (C), upper limit (D), growing degree days $(\mathrm{GDD})$ at $50 \%$ reduction $\left(\mathrm{I}_{50}\right)$ and $\mathrm{GDD}$ at $5 \%$ reduction $\left(\mathrm{ED}_{5}\right)$ for No PRE and PRE herbicides treatments on soybean plant dry matter. The $\mathrm{ED}_{5}$ value was used to estimate the critical time of weed removal (CTWR).

Tabela 4. Procenjeni parametri regresije pokazuju nagib linije (B), donji limit (C), gornji limit (D), sume efektivnih temperatura (GDD) za redukciju suve mase soje od $50 \%\left(\mathrm{I}_{50}\right)$ i GDD za redukciju od $5 \%\left(\mathrm{ED}_{5}\right)$ $\mathrm{u}$ varijanti sa i bez PRE-EM primene herbicida. Vrednost $\mathrm{ED}_{5}$ je korišćena za procenu kritičnog vremena uklanjanja korova (KVUK).

\begin{tabular}{|c|c|c|c|c|c|c|c|}
\hline \multirow{2}{*}{$\begin{array}{l}\text { Herbicide application } \\
\text { Primena herbicida }\end{array}$} & \multicolumn{4}{|c|}{ Regression parameters / Parametri regresije } & \multirow{2}{*}{ GDD } & \multirow{2}{*}{$\begin{array}{c}\mathrm{ED}_{5} \\
\text { DAE }^{\mathrm{a}}\end{array}$} & \multirow{2}{*}{$\mathbf{S G S}^{\mathbf{b}}$} \\
\hline & B & $\mathrm{C}$ & D & $I_{50}$ & & & \\
\hline No PRE & $2.06( \pm 1.2)$ & $30( \pm 11)$ & $176( \pm 12)$ & $342( \pm 42)$ & $100( \pm 16)$ & 10 & V1 \\
\hline PRE herbicides & $3( \pm 2.2)$ & $100( \pm 19)$ & $227( \pm 15)$ & $310( \pm 100)$ & $382( \pm 85)$ & 34 & V5 \\
\hline
\end{tabular}

${ }^{a}$ Days after emergence; ${ }^{b}$ Soybean growth stage 


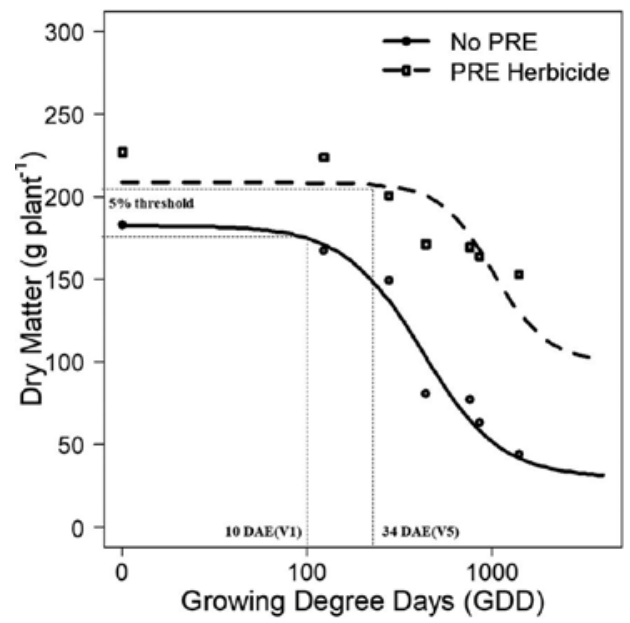

Figure 4. Soybean dry matter (g plant $\left.{ }^{-1}\right)$ as a function of increasing delay of weed removal for No PRE and PRE herbicides applications. Broken lines predicted with the four-parameter logistic model (Equation 2) used to determine the critical time of weed removal (CTWR) at $5 \%$ reduction. See Table 4 for parameter estimates.

Grafik 4. Uticaj vremena uklanjanja korova na suvu masu soje ( $\mathrm{g}$ biljci-1 $\left.{ }^{-1}\right) \mathrm{u}$ varijanti sa i bez zemljišne primene herbicida. Isprekidana linija predstavlja kritični period suzbijanja korova na osnovu redukcije suve mase od 5\% izračunat na osnovu log-logistic modela nelinearne regresione analize sa četiri parametara (jednačina 2). Vidi tabelu 4 sa procenjenim parametrima.

\section{DISCUSSION}

Soybean leaf area and dry matter were significantly reduced by the duration of weed interference. The longer the interference of weeds in soybeans or longer the timing of weed removal was delayed, the percentage reduction in soybean leaf area and dry matter was greater. The magnitude of reduction was greater in plots without PRE herbicides compared to plots with PRE herbicides. CTWR (based on a 5\% threshold) was calculated to be 10 DAE (V1), without PRE herbicides application, compared to $34 \mathrm{DAE}$ (V5) with PRE herbicides application. The difference of 24 DAE demonstrated that the PRE herbicides provided at least three weeks' protection of soybean growth, when compared to soybean grown without PRE herbicides.

Similar results were observed when CTWR was calculated based on crop yields. Pavlovic et al. (2017) reported that CTWR started at 14 DAE in plots without PRE herbicides, when compared to 46 DAE in plots with PRE herbicides, which coincided with V1 and V6 soybean growth stages.

\section{CONCLUSION}

The use of PRE herbicides clearly protected the soybean and could provide a time window of about three to four weeks after the crop emergence before the need for post-emergence application of glyphosate (in glyphosate-tolerant soybean) or other herbicides. In addition, 
PRE herbicides could also provide alternative modes of action for fighting the glyphosateresistant weeds in soybean.

\section{LITERATURE}

Adigun, J., Osipitan, A. O., Lagoke, S. T., Adeyemi, R. O., Afolami, S. O.: Growth and yield performance of cowpea (Vigna unguiculata (L.) Walp) as influenced by row-spacing and period of weed interference in South-West Nigeria. Journal of Agricultural Science, 6 (4), 188, 2014.

Beckie, H. J., Lozinski, C., Shirriff, S., Brenzil, C. A.: Herbicide-resistant weeds in the Canadian Prairies: 2007 to 2011. Weed Technology, 27 (1), 171-183, 2013.

Gilmore, E. C., Rogers, R. S.: Heat units as a method of measuring maturity in corn. Agronomy Journal, 50, 611-615, 1958.

Hall, M. R., Swanton, C. J., Anderson, G. W.: The critical period of weed control in grain corn (Zea mays). Weed Science, 40, 441-447, 1992.

Harker, K. N.: Slowing weed evolution with integrated weed management. Canadian Journal of Plant Science, 93 (5), 759-764, 2013.

Heap, I., Duke, S. O.: Overview of glyphosate-resistant weeds worldwide. Pest Management Science, 74 (5), 1040-104, 2018.

Knezevic, S. Z., Evans, S. P., Blankenship, E. E., Van Acker, R. C., Lindquist, J. L.: Critical period of weed control: the concept and data analysis. Weed Science, 50, 773-786, 2002.

Knezevic, S. Z.: Weeds species on the increase in eastern Nebraska. In the Proceedings of the 2006 Crop Protection Clinics. Lincoln, NE: University of Nebraska, 122-131, 2006.

Knezevic, S. Z.: Herbicide tolerant crops: 10 years later. Maydica, 52, 245-250, 2007.

Knezevic, S. Z., Streibig, J. C., Ritz, C.: Utilizing R software package for dose-response studies: the concept and data analysis. Weed Technology, 21, 840-848, 2007.

Knezevic, S. Z., Klein, R. N.: Glyphosate dose response curves and selectivity for control of problem weeds in Roundup-Ready soybean. In the Proceedings of the North Central Weed Control Conference. Weed Science Society, 60, 149, 2005.

Leeson, J. Y., Thomas, A. G., O'Donovan, J.: Economic impact of alien weeds on wheat, barley and canola production. In the Proceedings of the Annual Meeting. Canadian Weed Science Society, Victoria, BC. p. 90, 2006.

Molugeta, D., Boerboom, C. M.: Critical time of weed removal in glyphosate-resistant Glycine max. Weed Science, 48, 35-42, 2000.

Osipitan, O. A., Adigun, J. A., Kolawole, R. O.: Row spacing determines critical period of weed control in crop: cowpea (Vigna unguiculata) as a case study. Azarian Journal of Agriculture, 3 (5), 90-96, 2016.

Pavlovic, P., Jhala, A., Barnes, E., Beiermann, C., Lawrence, N., Scott, J., Osipitan, O. A., Knezevi, S. Z.: Effects of Timing of Weed Removal and PRE Herbicides on Growth and Yield of Soybean. In the Proceedings of the $72^{\text {nd }}$ Annual Meeting, North Central Weed Science Society; St. Louis, MO, 2017.

R Development Core Team.: R: A Language and Environment for Statistical Computing. R Foundation for Statistical Computing, Vienna, Austria, 2017.

Teasdale, J. R.: Influence of narrow row/high population corn (Zea mays) on weed control and light transmittance. Weed Technology, 9, 113-118, 1995.

Wilson, R. G., Miller, S. D., Kniss, A. R., Westra, P., Stahlman, P. W.: Risk of weed spectrum shirts and herbicide resistance in irrigated Roundup- Ready cropping systems - a western Nebraska perspective after 8 years. In the Proceedings of the $60^{\text {th }}$ Annual Meeting of the North Central Weed Science Society, Kansas City, Missouri, 60, 138, 2005. 


\title{
Uticaj vremena uklanjanja korova i PRE-EM primene herbicida na rast useva soje
}

\begin{abstract}
REZIME
Poljski ogledi su izvedeni tokom 2017. godine na lokalitetu Concord na severoistoku savezne države Nebraska, SAD. Cilj ogleda je bio da se oceni kako različita vremena uklanjanja korova i primena PRE-EM herbicida utiču na rast i razvoj useva soje. Ogled je rađen po principu splitplot rasporeda sa 14 tretmana (2 različita režima primene PRE-EM herbicida i 7 različitih vremena uklanjanja korova) u četiri ponavljanja. Dva režima primene PRE-EM herbicida: režim bez primene PRE-EM herbicida i režim sa primenom PRE-EM herbicida na bazi mešavine sulfentrazona i imazetapira ( $140 \mathrm{i} 28 \mathrm{~g}$ a.s. ha ${ }^{-1}$ ). Sedam vremena uklanjanja korova je bilo: V1, V3, V6, R2 i R5 faza razvoja soje, kao i nezakorovljena i zakorovljena kontrola. Vegetativni parametri soje (lisna površina i suva masa) su ocenjivani tokom R6 faze razvoja useva. Odloženo vreme uklanjanja korova je imalo značajnog uticaja na rast soje, time što su lisna površina i suva masa bili značajno redukovani. Bez primene PRE-EM herbicida redukcija lisne površine i suve mase soje za 5\% se poklopilo sa odlaganjem uklanjanja korova od 100 GDD nakon nicanja soje (što korespondira sa V1 fazom razvoja soje, odnosno 10 dana nakon nicanja [DNN] useva). Međutim, primena PRE-EM herbicida je dodatno odložila ovo smanjenje, što korespondira sa 382 GDD nakon nicanja soje (što se poklapa sa V5 fazom razvoja soje, odnosno sa $34 \mathrm{DNN}$-a soje). Na osnovu dobijenih rezultata može se konstatovati da primena PRE-EM herbicida može da zaštiti soju od smanjenja rasta i odloži POST-EM primenu herbicida i do tri nedelje nakon nicanja useva. Ključne reči: kompeticija korova i useva, soja, PRE-EM herbicidi, rast i razvoj useva.
\end{abstract}

